\title{
Associated Causes of Low Productivity of Indigenous Beef Cattle Farming under the Pastoral Systems of the North West Region of Cameroon
}

\author{
P. Y. Lawan \\ Divisional Delegation of Livestock \\ Fisheries and Animal Industries \\ North West Region of Cameroon \\ G. A. Musongong \\ Bamenda University of Science and Technology (BUST) Bamenda \\ Cameroon \\ H. M. Ndofor-Foleng \\ Department of Animal Science \\ University of Nigeria \\ Nsukka \\ M. H. N. Atanga \\ National Veterinary School, Jakiri, \\ North West Region \\ Cameroon
}

\begin{abstract}
Management practices play a big role in animal productivity reflected either in financial returns or food sufficiency. A cross sectional study was undertaken to determine the factors associated with low productivity of indigenous beef cattle farming under the pastoral systems in seven administrative divisions of the North West Region of Cameroon. A total of 150 questionnaires were administered to pastoralists, butchers and animal service providers. At the Municipal Abattoir body condition scores of cows and the number of cows to be slaughtered were taken. All foetuses from slaughtered cows were recovered and identified according to age and sex. Results were entered into SPSS software version 20.0 and analyzed by using the Chi square Test. Out of the 494 cows slaughtered during the period of study 73 (14.8\%) were pregnant and had poor body condition scores (1-2). Forty two (57.5\%) of 2-3 months old foetuses recovered were female and 31 (42.5\%) were male. Thus there was $14.8 \%$ potential calf wastage. The predominant associated causes of low productivity of pastoral farms frequently observed by the pastoralists were poor growth of the cattle (34.0\%), loss of foetuses through abortions/pregnant cow slaughter (21.3\%), delayed estrus (20.0\%) and lastly increased calving intervals (14.7\%). Abattoir recoveries revealed that loss of 2-3 months old foetuses was higher $(p<0.003)$ than loss of 4-6 months olds. There was also loss of at least 10 adult cattle a year reported by 69.0\% pastoralists as a result of suspected bovine trypanosomiasis among other unknown causes. It was concluded that management practices namely transhumance, stocking density, sale and slaughter of cows, poor feed, lack of veterinary attention contributing to poor growth, poor health, abortions, calf wastage and adult mortality are serious associated causes of low productivity of pastoral farms of the North West Region of Cameroon. The rate of potential cow loss through foetal wastage is alarming especially as the majority of foetuses were female.
\end{abstract}

Key Words: Gudali, Fulani, management, foetus, productivity, pastoralist, Cameroon

\section{Introduction}

Productivity of a pastoral management system refers to the effectiveness of the production effort in terms of quality and quantity. Efforts put in such a system focus on provision of food, medical care, prevention of disease, hygiene, close monitoring and off take to mention a few. The North West Region of Cameroon with a surface area of $17,836 \mathrm{~km}^{2}$ is predominantly an agro-pastoral region and has a human population of about 1,728,953 as estimated in the 2008 population census. The region ranks third in cattle production after Adamawa and Far North Regions with a cattle population of 1,568,431 (EPIA STAT, 2017) which are mainly Gudali and Fulani breeds. This gives virtually a 1:1 man to cattle ratio. About $80 \%$ of the rural population depend solely on agriculture and constitute a strong livestock production sub-sector (Fung et al., 2014). 
Cattle production is the mainstay for livestock farmers and provides direct employment to 166166 (9.61\%) people (MINEPIA, 2015). Apart from being an important source of animal protein, hides, manure, bone and income cattle production also offers other services (Ndenecho and Balgah, 2007). Cattle production systems vary from extensive to semi intensive and those who possess large herds on poor pasture land practice transhumance as routine. During such a period prenatal mortality, abortions and neonatal deaths resulting from a multitude of causes could be up to $75 \%$ in poorly supervised farms according to Silva et al., (2013). In the North West Region pastoral farm productivity has hardly been adequately assessed and documented. The present work aims at identifying some of the productivity constraints in order to suggest possible solutions.

\section{Materials and methods}

\section{Study area}

The North West Region of Cameroon has very diverse climatic conditions and ecological zones which favor cattle production. The topography is characterized by mountains, plateaux, valleys and flood plains in intermountain basins (Neba, 2010). It experiences two distinct seasons namely the rainy season (mid-March to mid-October) and the dry season (mid-October to mid-March). Annual rainfall varies from $1500 \mathrm{~mm}$ to over $3000 \mathrm{~mm}$ and the average relative humidity (RH) is up to 65\% (Ngane et al., 2012).Temperatures vary from less than $15^{\circ} \mathrm{C}$ on the high mountainous areas to above $27^{\circ} \mathrm{C}$ in the low altitude zones (Neba, 2010). The study area chosen for the present work includes 30 subdivisions in seven administrative divisions namely Boyo, Bui, Donga-Mantung, Menchum, Mezam, Momo, Ngoketunja.

\section{Data collection}

Questionnaires were administered to pastoralists and animal service providers in each of the seven divisions and a total of 150 were recovered. Contacts with randomly selected respondents were made in the cattle grazing land, the Bamenda cattle market and the Bamenda Municipal abattoir. In the cattle market and municipal abattoir physical examination of the anatomical landmarks, such as bony prominence of the chest region, spinous processes and back bones was done and scored on a scale of 1-5 for body condition recommended by Eversole (2009); Tasew and Duguma (2012). Foetuses recovered from slaughtered cows were classed according to age and sex where possible and the number recovered per period was recorded. Data was collated and entered into SPSS software version 20.0 and Microsoft Excel and was analyzed using Chi square Test. At 95\% C.I $(\alpha=0.05)$ differences were considered significant. Results were presented in tables and histograms.

\section{Results}

Table 1: Number of cattle slaughtered per month

\begin{tabular}{llll}
\hline Month & Male & Female & Total \\
\hline January & 386 & 84 & 470 \\
February & 167 & 72 & 239 \\
March & 409 & 130 & 539 \\
April & 351 & 136 & 487 \\
\hline May & 399 & 156 & 555 \\
Total & 1712 & 578 & 2290 \\
\hline Mean & 342.4 & 115.6 & 458 \\
\hline \% slaughter & $74.8 \%$ & $25.2 \%$ & $100 \%$ \\
\hline
\end{tabular}

Table 2: Age and number of cattle slaughtered

\begin{tabular}{llllllllll}
\hline \multicolumn{7}{l}{ Age of cattle (years) slaughtered } \\
\hline Age & 3 & 4 & 5 & 6 & 7 & 8 & 9 & 10 & Total \\
Number & 12 & 63 & 111 & 110 & 71 & 32 & 02 & 01 & $\mathbf{4 0 2}$ \\
& $\mathbf{7 5 ( 1 8 . 7 \% )}$ & $\mathbf{2 2 1}(\mathbf{5 5 \% )}$ & $\mathbf{1 0 3}(\mathbf{2 5 . 7 \% )}$ & $\mathbf{0 3}(\mathbf{0 . 7 5 \% )}$ & \\
\hline
\end{tabular}


Table 3: Number of foetuses recovered during of transhumance

\begin{tabular}{llll}
\hline Month & Male foetuses & Female foetuses & Total \\
\hline January & 5 & 5 & 10 \\
February & 1 & 1 & 2 \\
March & 3 & 8 & 11 \\
April & 7 & 8 & 15 \\
May & 20 & 25 & 45 \\
Total & $\mathbf{3 6}$ & $\mathbf{4 7}$ & $\mathbf{8 3}$ \\
Percentage & $36 / 83=43.4 \%$ & $47 / 83=56.6 \%$ & $83 / 578=14.4 \%$ \\
Mean & 7.2 & 9.4 & 16.6 \\
\hline
\end{tabular}

Table 4: Number of foetuses recovered per trimester

\begin{tabular}{|c|c|c|c|c|c|c|c|c|c|}
\hline \multirow[t]{3}{*}{ Month } & \multicolumn{6}{|c|}{ Trimester } & \multicolumn{3}{|c|}{ Total } \\
\hline & \multicolumn{2}{|c|}{1} & \multicolumn{2}{|l|}{2} & \multicolumn{5}{|l|}{3} \\
\hline & Male & Female & Male & Female & Male & Female & All & Male & Female \\
\hline January & 3 & 4 & 2 & 1 & 0 & 0 & 10 & 5 & 5 \\
\hline February & 1 & 0 & 0 & 1 & 0 & 0 & 2 & 1 & 1 \\
\hline March & 2 & 5 & 1 & 3 & 0 & 0 & 11 & 3 & 8 \\
\hline April & 4 & 4 & 2 & 3 & 1 & 1 & 15 & 7 & 8 \\
\hline May & 15 & 20 & 4 & 3 & 1 & 2 & 45 & 20 & 25 \\
\hline Total & 25 & 33 & 9 & 11 & 2 & 3 & 83 & 36 & 47 \\
\hline $\begin{array}{l}\% \text { per } \\
\text { Trimester }\end{array}$ & $69.9 \%$ & & $24.1 \%$ & & $6.0 \%$ & & & $43.4 \%$ & $56.6 \%$ \\
\hline
\end{tabular}

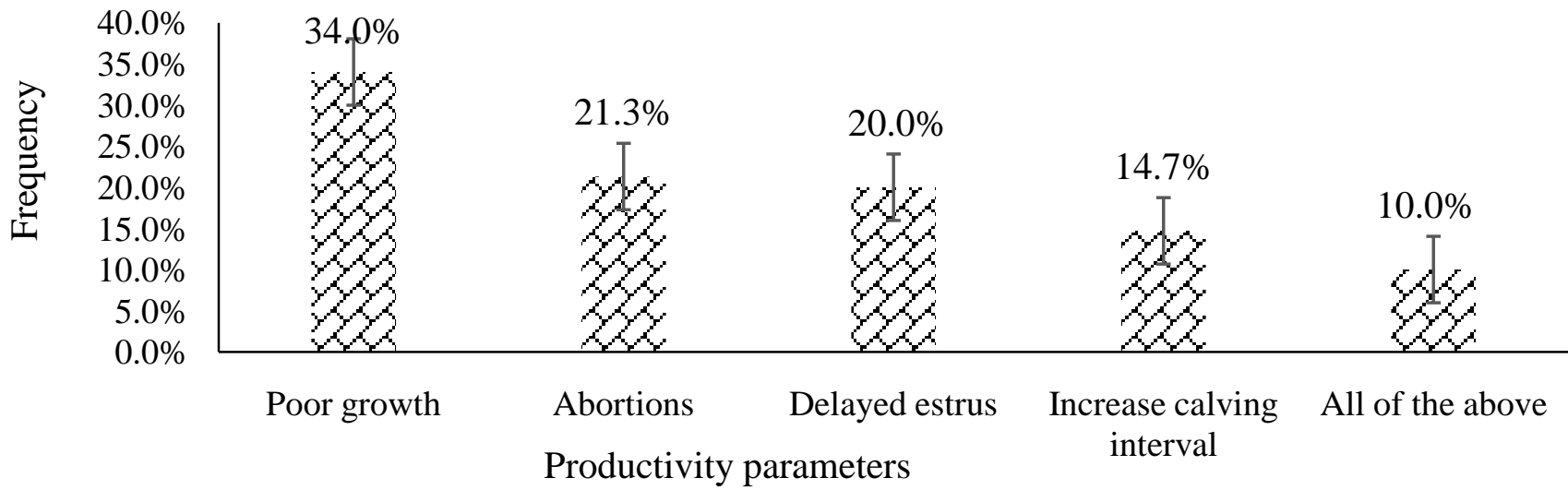

Figure 1: Perceptions of pastoralists on effects of management on production parameters

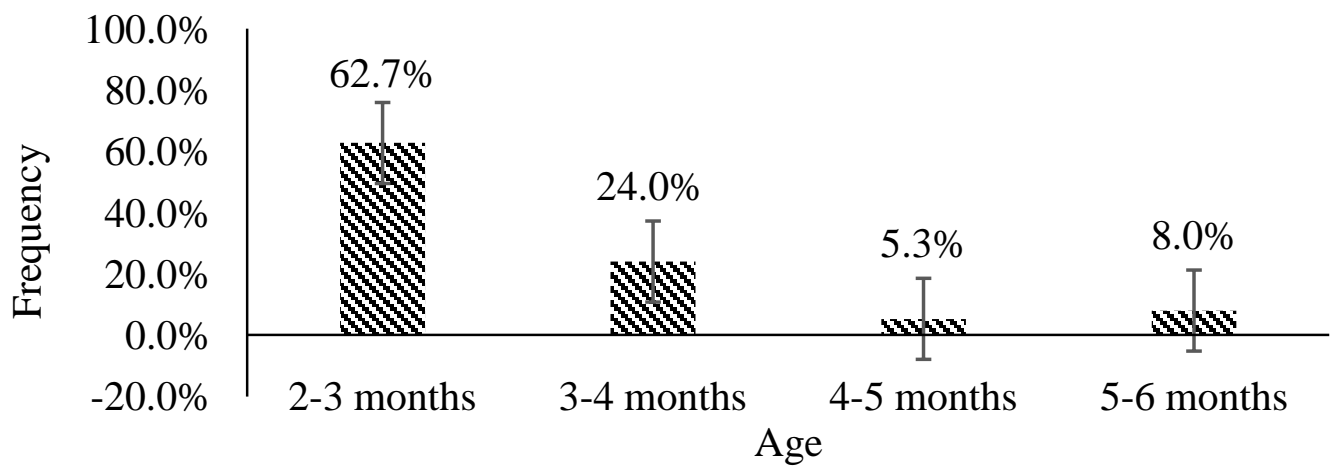

Figure 2: Ages of foetuses recovered at slaughter 


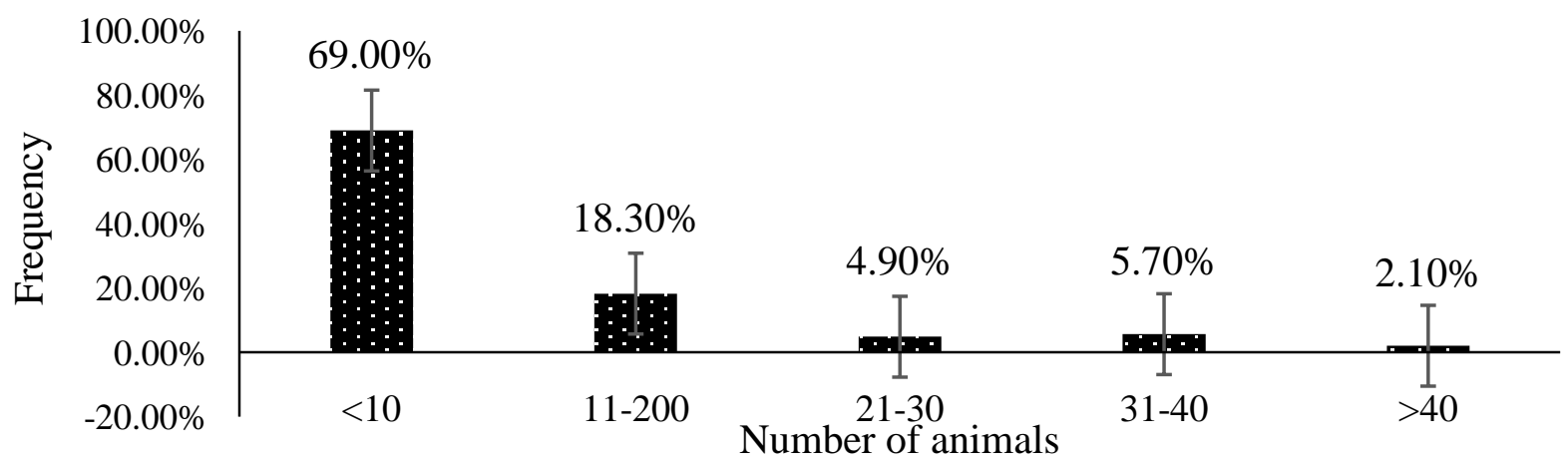

Figure 3: Number of animals that die per year in each farm

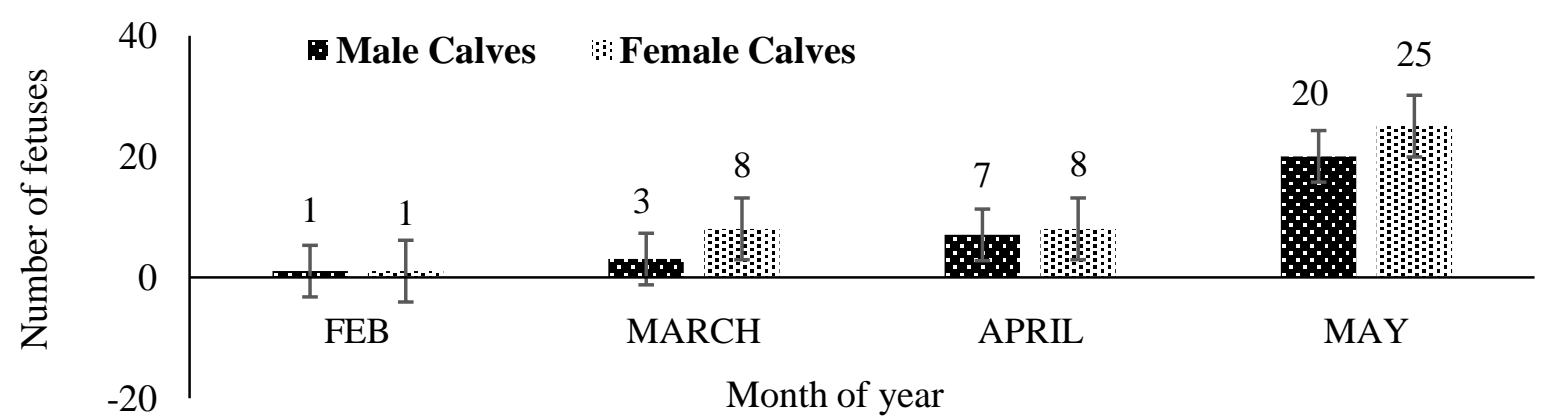

Figure 4: Number of fetuses/calves recovered from the slaughter house each month

The majority (74.8\%) of cattle slaughtered during the period were bulls and $25.2 \%$ female. In all 55\% were 5-6 years old and $25.6 \%$ were $7-8$ years old while $0.75 \%$ was more than 8 years old. Thus overall off take ratio of male to female is $3: 1$ in four months.

In Figure 1 the perceived effects in descending order of frequency as explained by the respondents were poor growth of the cattle (34.0\%), abortions (21.3\%), delayed oestrus (20.0\%) and increased calving intervals (14.7\%). Some (10.0\%) of the respondents noticed all the above defects in their herds of cattle.

Figure 2 shows that the majority of foetuses (62.7\%) recovered from the slaughtered cows in the abattoir were 2-3 months old and fewer were 4-6 months old. While loss of 2-3 months old foetuses was highest, losses decreased significantly with advancing age of pregnancy and this was very evident at 4-6 months of pregnancy. Irrespective of trimester of pregnancy there were always more female foetuses; the number of foetuses of $3^{\text {rd }}$ trimester was least $(6 \%)$. Figure 3 shows that whereas most cattle owners (69.0\%) each lost below 10 adult cattle a year 5.7\% each could lose as many as 30 or 40 cattle a year. Figure 4 shows the high level of reproductive losses during the interphase between the dry and rainy seasons from cows which were sold for slaughter.There is a tremendous increase in the number of foetuses harvested at slaughter from February to May rising from of 02 to 45 foetuses (average 18.25) per month (Figure 4).

Data shows that 73 out of a total of 494 cows (14.8\%) slaughtered were 2-6 months pregnant and that 31 out of 73 $(42.5 \%)$ were male while $42(57.5 \%)$ were female foetuses. So there is $14.8 \%$ foetal wastage within a period of 4 months out of which $62.7 \%$ were $<3$ months old.The cows incalf presented for slaughter generally had poor body condition scores of 1-2. The number of adult cattle that die in a year in pastoral farms especially during the dry season is summarized in Figure 3. Some pastoralists could each lose up to 40 animals during this period.

\section{Discussion}

There is a strong link between the body condition of a cow and her reproductive performance (Eversole et al., 2009). Low productivity of a cattle production industry is predisposed by poor body condition scores, mortality, abortion, reduced fertility, long calving intervals, delayed oestrus, reduced milk and meat production and inability to work as traction animals; there is increase in the cost of livestock management in general (Chanie et al., 2013). Some of these factors namely poor body condition, abortion, foetal wastage, long calving intervals and delayed oestrus are very evident in the pastoral farms of the North West Region. 
It has long been known that a sedentary management system involving moderate stocking is usually more preferable than the nomadic and transhumant system with large numbers of cattle (Williamson and Payne, 1965). This is encouraged where possible following pasture improvement. The direct effects of management practices in pastoral production systems are complicated by stocking rate, seasonal shortage of fodder which becomes too dry and scanty for large herds and health problems during the dry season arising from contact with carriers of infectious diseases (Muhanguzi, et al., 2017). Animals also consume contaminated pasture in communal grazing lands during transhumance especially. Most animals taken for slaughter at this time are pregnant and infected and not in good condition on coming back from transhumance. Productivity also drops because the greater the number of cattle composing a unit the less the attention which can be given to each individual. In breeding operations this means a lower percentage of calving (Williamson and Payne, 1965) associated with long calving intervals. Long calving intervals reported in the present work may also be related to the large herd sizes with few bulls in the herds. In moderate stocking barren cows and shy breeders can easily be discovered and dealt with. When cattle assemble in the communal grazing land during transhumance (Jittapalopong et al, 2009; Sam-Wobo et al., 2010; Majekodunmi, 2013; Silva et al., 2013) some of them suffer from acute trypanosome as is become blind, emaciated and weak and pregnant cows usually abort especially during early pregnancy. DREPIA-NW (2018) has associated enormous losses with trypanosomes is in the North West Region. The economic consequences of foetal wastage to farm productivity are very obvious in monetary terms.

For instance if a zebu cow can calve averagely eight times during her reproductive life before it is culled then 42 female calves lost X 8 times calving means a total of 336 cattle would be lost. This projected number of cattle would be lost potentially as wasted foetuses just in the four months of the present work. If one adult weighing $250 \mathrm{~kg}$ costs US\$ 400 (200,000 francs CFA) it therefore means that US\$134,400 (67.2 million francs CFA) was lost. Ndi et al., (1993) estimated <3 months old calf wastage to be $35.9 \%$ and $>51.9 \%$ aged more than 4 months (average annual loss of $22.1 \%$ ) in the same Bamenda Municipal abattoir by the end of one year. Foetal wastage seems to be commonplace in African production systems as indicated from Ghana (18.4\%), Nigeria (10.7\%), Tanzania (15.6\%) by reports of Atalwana, et al., (2013); Oduguwa et al., (2013) and Nonga (2015). A long list showing the magnitude of slaughter of pregnant cows in African countries in 1984-2014 is presented by Nonga (2015). The present study has registered foetal wastage of $14.8 \%$ in 4 months which means that figures could rise by the end of the year, all being equal, to $44.4 \%$ representing 219 calves. Many years after Ndi et al (1993) Jalousie et al., (2018) recorded $34.3 \%$ calf wastage in three months of the rainy season (July-September) only in the same Bamenda Municipal abattoir. Whereas slaughter of cows with older pregnancies seems to have reduced there is increased inability to detect early pregnancies as indicated by the far higher number of $<3$ months old foetuses recovered in the present work.

Apart from disease and seasonal effects movement during transhumance which requires energy would likely be another cause of weight loss also making them become weak.Under good husbandry conditions even during transhumance the Gudali fattens within a shorter time compared to the others (Williamson and Payne, 1965) and so could improve farm productivity better than the other breeds. The causes of death in individual farms are not clear but the dry season and its problems may indirectly contribute. Tesfaye et al., (2012) and Majekodunmi et al., (2013) attributed significantly reduced productivity to sporadic deaths. Lowered nutritional level and large herds with few bulls can increase the calving interval which together with abortion can be serious components of lowered reproductive performance of breeding animals since such cases are usually prematurely culled for being unproductive. Pasture deficient in minerals is another factor involved in poor growth, low fertility, weakness of calves and even foetuses (Williamson and Payne, 1965).

Pastoralists hardly alleviate the situations highlighted above say by control of stocking rate, pasture improvement to reduce transhumance and becoming more sedentary, using feed supplements and medication, practicing general hygiene, restricting indiscriminate breeding during transhumance and detecting early pregnancy. Many cows return from transhumance carrying pregnancies of various ages, some of which even if identified mean nothing to the butcher at the slaughterhouse. In addition to these shortcomings possessing large herds makes it difficult to quickly monitor them and detect production problems in time (Williamson and Payne, 1965).

\section{Conclusions}

Management practices such as stocking rate, open range grazing, transhumance, off take and sale, open breeding, vector control and many others have a great impact on cattle productivity in the North West Region of Cameroon. Poor growth, abortion, foetal loss at slaughter and high mortality rate of adult animals decrease pastoral farm productivity. One of the major causes of low productivity is indirect calf wastage and attention should be drawn toward perpetual foetal wastage and modern farming systems adopted in order to improve and increase productivity of pastoral farms. 


\section{Acknowledgements}

The authors acknowledge the collaboration of the staff of MINEPIA for their support in data collection, the butchers in the Bamenda Municipal abattoir for their patience during the period of study.

\section{References}

Chanie, M., Adula, M., Bogale, B. (2013) Socio-Economic Assessment of the Impacts of Trypanosomiasis on Cattle in Girja District, Southern Oromia Region, Southern Ethiopia, Acta Parasitologica Globalis 4 (3): 80-85.

DREPIA-NW (2018) Regional Delegation of Livestock, Fisheries and Animal Industries, North West Region, Annual Report

EPIASTAT, (2017) Annuaire statistiques du sous-secteur élevage, pêche et industries animales 2016. $\mathrm{N}^{0} 005$ pp. 15 Encours de validation

Eversole, D. E., Browne M. F., Hall, J. B., Deitz, R. E., (2009) Body condition scoring of beef cows, Vtechwork.lib.vt.edu accessed 31/10/2015, 12.05

Fung C., Tata S., Gwanfobe M., (2014) The political situation of the highlands of Cameroon, Journal of African History 3: 312-319

Jalousie, N. B. F.., Nsadzetsen, G., Mbiba,, H. F., Wirndzerem, F. N., Isabelle, L. W., Munji, V. N., Bayemi, P. H. D., (2018), Incidence of foetal wastage in cattle slaughtered and its economic implications at the Bamenda City Slaughter House, Cameroon, International Journal of Veterinary Sciences and Animal Husbandry 3(6):14-18

Jittapalapong, S., Pinyopanuwat, N., Inpankaew, T., Sangvaranond, A., Phasuk, C., Chimnoi, W., Kengradomkij, C., Kamyingkird, K., Sarataphan, N., Desquesnes, M., Arunvipus, P. (2009), Prevalence of Trypanosoma evansi Infection Causing Abortion in Dairy Cows in Central Thailand,Kasetsart L. Nat. Sci. 43:53-57.

Majekodunmi, A. O., Fajinmi, A., Dongkum, C., Picozzi, K., Thrusfield, M. V., Welburn, S. C., (2013) A longitudinal survey of African animal trypanosomiasis in domestic cattle on the Jos Plateau, Nigeria: Prevalence, distribution and risk factors. Parasites and Vectors 6:1-10

MINEPIA (2018) Ministère de I' Élevage, des Pèches et des Industries Animales, North West Region 2010-2018 Annual Reports

Ndenecho, E., Balgah, S., (2007) The population-Resource Security and Conflict Trinity: Analysis of North West Cameroon ( $1^{\text {st }}$ edition), Unique Printers, Bamenda, Cameroon

Ndi, C., Tambi, N. E., Agharih, N. W., (1993), Reducing calf wastage from the slaughter of pregnant cows in Cameroon, World Animal Review 77: 4-10

Neba, N. E., (2010) Indigenous Trees and Shrubs in Silvopastoral Systems of the Bamenda Highlands of Cameroon, Global Journal of Human Social Science 10 (3): 56-64.

Ngane, E. B.,Ngane, B. K., Ndjib, G., Awah, E. T., and Ehabe, E. E., (2012), Land consumption and related degradation patterns by major agricultural uses in the humid tropical Savannah of North West Cameroon, Agricultural Science Research Journal 2(6):318-323

Nonga, H. E., (2015), A review of cattle foetal wastage during slaughter and its impact to the future cattle herds in Tanzania, Livestock Research for Rural Development 27 (1) 2015:

Sam-Wobo, S. O., Igenezoa, A. J., Idowu, O. A., Otesile, E. B., Ekpo, U. F., Kehinde, O. O., (2010) Bovine trypanosomiasis and its impact on cattle in derived savanna areas of Ogun State, Nigeria, Journal of Public Health and Epidemiology 1(3):43-47.

Silva, T. M. F., Olinda, R. G., Rodrigues, C. M. F., Camera C. L. A., Lopes, F. C., Coelho, W. A. C., Ribeiro, M. F. B., Freitas, C. L. A, Marta, M.G.T., Bastita, S., (2013) Pathogenesis of reproductive failure induced by Trypanosoma vivax in experimentally infected pregnant ewes. Veterinary Research 44 (1) $15-24$

Tesfaye, D., Speybroeck, N., De Denken, R., Thys, E., (2012) Economic burden of bovine trypanosomiasis in three villages of Metekel zone, northwest Ethiopia, Tropical Animal Health and Production 44(4):873-879

Williamson G., Payne W. J. A., (1965) An Introduction to Animal Husbandry in the Tropics (2 ${ }^{\text {nd }}$ edition), Longman, Green and CO Ltd, London, 447pp 